\title{
PEMBERDAYAAN USAHA MIKRO KECIL MENENGAH (UMKM) CENDAWAN HOUSE KELURAHAN TEBING TINGGI OKURA KOTA PEKANBARU
}

\author{
Syed Agung Afandi ${ }^{1)}$, Muhammad Arif ${ }^{2}$, Santi Widiasari ${ }^{3)}$, Muslim Afandi ${ }^{4)}$
}

1) Program Studi Ilmu Pemerintahan, Fakultas Ilmu Sosoal dan Ilmu Politik, Universitas Abdurrab, Pekanbaru

2) Program Studi Ilmu Komunikasi, Fakultas Ilmu Sosoal dan Ilmu Politik, Universitas Abdurrab, Pekanbaru

3) Program Studi Pendidikan Dokter, Fakultas Kedokteran Dan Ilmu Kesehatan, Universitas Abdurrab, Pekanbaru

4) Program Studi Manajemen Pendidikan Islam, Program Pascasarjana, UIN Suska Riau Email: syedagungafandi@gmail.com

\begin{abstract}
ABSTRAK
Usaha Mikro Kecil Menengah (UMKM) memiliki peranan penting dalam perekonomian negara, baik dari sisi penciptaan lapangan kerja maupun dari sisi jumlah usaha. UMKM Cendawan House memiliki kendala dalam aktivitas usahanya berupa belum dimilikinya pembukuan yang baik, struktur, dan pembagian tugas sehingga berdampak pada tingkat produktivitas dan pemasaran produk yang dihasilkan. Berdasarkan latar belakang tersebut maka dilaksanakan kegiatan pengabdian dengan mitra pengabdian yakni UMKM Cendawan House yang berada di Kelurahan Tebing Tinggi Okura, Kecamatan Rumbai Pesisir, Kota Pekanbaru, Provinsi Riau. Kegiatan pengabdian yang dilakukan yakni pemberdayaan melalui sosialisasi manajemen usaha untuk mengatasi masalah manajemen UMKM Cendawan House. Hasil dari kegiatan ini adalah mitra memiliki pembukuan yang baik, struktur, dan pembagian tugas serta wewenang yang jelas yang kemudian juga berdampak positif terhadap peningkatan produksi dan pemesaran produk yang dihasilkan. Dari kegiatan ini disimpulkan bahwa permasalahan yang dihadapi mitra dapat diselesaikan setelah pelaksanaan kegiatan ini.
\end{abstract}

Kata Kunci: UMKM, Cendawan House

\section{ABSTRACT}

Micro, Small and Medium Enterprises (MSMEs) have an important role in the country's economy, both in terms of job creation and in the number of businesses. Cendawan House MSMEs has problems in its business activities in the form of not having good bookkeeping, structure, and division of tasks so that it has an impact on the level of productivity and marketing of products produced. Based on this background, a service activity was carried out with a service partner namely Cendawan House MSMEs in Tebing Tinggi Okura, Pekanbaru City, Riau Province. The dedication activities carried out were business management socialization to overcome the management problems of Cendawan House MSMEs. The results of this activity are partners have good bookkeeping, structure, and division of tasks and clear authority which then has a positive impact on increasing production and enlargement of the products produced. From the activities, it was concluded that problems faced by partners can be resolved after the implementation of this activity.

Key words: MSMEs, Cendawan House 


\section{PENDAHULUAN}

Pemberdayaan Usaha Mikro Kecil Menengah (UMKM) secara umum diarahkan untuk mendukung upaya penanggulangan kemiskinan dan kesenjangan serta penciptaan kesempatan kerja dan peningkatan ekspor, sehingga sektor usaha mikro kecil menengah memegang peranan yang sangat penting dalam membangun perekonomian masyarakat saat ini. Kendala yang dihadapi mayoritas usaha mikro kecil menengah di Indonesia saat ini adalah rendahnya tingkat produktivitas, rendahnya nilai tambah, dan rendahnya kualitas produk. Meski demikian diakui bahwa usaha mikro kecil menengah telah menciptakan jutaan lapangan kerja bagi masyarakat.

Usaha Mikro Kecil Menengah Cendawan House merupakan UMKM yang terletak di Kelurahan Tebing Tinggi Okura Kecamatan Rumbai Pesisir Kota Pekanbaru. UMKM Cendawan House beranggotakan 15 orang dan berdiri sejak tahun 2015 serta merupakan inisiasi pemuda setempat. UMKM Cendawan House saat ini telah membuka lapangan kerja bagi anak-anak putus sekolah, pelajar dan mahasiswa setempat. Saat ini di dalam bangunan berdinding kayu seluas luas 20 × 7 meter, Usaha Mikro Kecil Menengah Cendawan House telah memiliki 8000 baglog.

Baglog merupakan media penanaman jamur. Setelah melalui proses pembuatan dan berusia 3 bulan, baglog akan mulai ditumbuhi jamur. Satu baglog bisa dipanen hingga empat bulan dengan jangka waktu panen berselang 3 hari. Setelah 4 bulan baglog tidak lagi bisa memproduksi jamur sehingga harus diganti dengan adonan baru. Dalam sekali panen, 1 baglog dapat menghasilkan 3 - 5 ons jamur. Setiap harinya UMKM Cendawan House telah menghasilkan 15 - 25 kilogram jamur segar. 1 kilogram jamur segar dijual dengan harga Rp. 30.000 sehingga dalam sehari nilai penjualan dapat mencapai $\mathrm{Rp}$ 450.000 hingga $\mathrm{Rp} 750.000$.

Jamur tiram sagar produksi Cendawan House saat ini baru dipasarkan terbatas pada masyarakat sekitar serta pasar tradisional, sedangkan olahan jamur titram berupa pizza jamur, jamur krispi, nagget jamur dan sate jamur yang dibandrol seharga Rp12.000 - Rp15.000 baru akan diproduksi jika ada event tertetu atau menunggu pesanan pelanggan.

Permasalahan yang dihadapi Usaha Mikro Kecil Menengah Cendawan House adalah belum dimilikinya pembukuan yang baik serta belum adanya strukur dan pembagian tugas yang jelas sehingga pengelolaan Cendwan House saat ini cenderung bertumpu pada beberapa orang. Hal ini terjadi dikarenakan UMKM Cendawan House secara status kepemilikan merupakan miliki bersama sehingga sangat memerlukan adanya struktur dan pembagian tugas yang jelas antar anggota. Inilah yang kemudian berimbas pada belum optimalnya produktivitas dan pemasaran yang dilakukan UMKM Cendawan House.

Kegiatan ini betujuan untuk meningkatkan produktivitas Usaha Mikro Kecil Menengah Cendawan House melalui kegiatan pemberdayaan sehingga sasaran memiliki sturktur, pembagian tugas, strategi pemasaran, serta pembukuan yang baik yang akan berdampak pada pemasaran dan peningkatan produksi, baik dalam bentuk mentah maupun olahan siap saji sehingga akan meningkatkan profit UMKM Cendawan House.

\section{TINJAUAN PUSTAKA}

\section{Usaha Mikro Kecil Menengah (UMKM)}

Usaha Mikro Kecil Menengah (UMKM) adalah unit usaha produktif yang berdiri sendiri, yang dilakukan oleh orang perorangan atau badan usaha disemua sektor ekonomi. 
Pada prinsipnya, pembedaan antara Usaha Mikro (UMI), Usaha Kecil (UK), Usaha Menengah (UM), dan Usaha Besar (UB) umumnya didasarkan pada nilai aset awal (tidak termasuk tanah dan bangunan), omset rata-rata per tahun, atau jumlah pekerja tetap. Namun definisi UMKM berdasarkan tiga alat ukur ini berbeda menurut negara. Karena itu, memang sulit membandingkan pentingnya atau peran UMKM antar negara (Tambunan, 2012).

Menyadari pentingnya UMKM, tidak heran mengapa pemerintah dihampir semua NSB (termasuk Indonesia) mempunyai berbagai macam program, dengan skim-skim kredit bersubsidi sebagai komponen terpenting, untuk mendukung perkembangan dan pertumbuhan UMKM. Tidak hanya itu, lembaga-lembaga internasional seperti Bank Dunia, Bank Pembanunan Asia (ADB), dan organisasi dunia untuk industri dan pembangunan (The United Nation Industry dan Development Organisation/UNIDO) dan banyak negara donor lewat kerja sama bilateral juga sangat aktif selama ini dalam upayaupaya pengembangan (capacity building) UMKM di NSB (Abeng, 2015).

Pengembangan UMKM sangat relevan di Indonesia dapat dilihat dari beberapa pertimbangan berikut (Yustika, 2007):

1. Struktur usaha di Indonesia selama ini bertumpu kepada keberadaan UMKM, tetapi dengan kondisi yang memprihatinkan baik dari segi nilai tambah maupun keuntungan yang bisa diraih. Dengan memajukan kelas usaha tersebut secara otomatis membangun kesejahteraan sebagian besar masyarakat.

2. Tanpa disadari cukup banyak UMKM yang selama ini berorientasi ekspor sehingga sangat membantu pemerintah dalam mendapatkan devisa. Hal ini tentu berkebalikan dengan industri besar yang justru mengeksploitasi pasar domestik untuk penjualan.

3. Sektor UMKM telah terbukti lebih fleksibel dalam berbagai kondisi perekonomian yang tidak menguntungkan. Pada saat industri besar telah gulung tikar, sebagian industri kecil masih bertahan bahkan memperoleh keuntungan berlipat bagi yang berorientasi ekspor.

4. Sektor UMKM lebih banyak memakai bahan baku (intermediate goods) dari dalam negri sehingga tidak membebani nilai impor seperti yang selama ini dipraktikkan oleh industri.

Perkembangan UMKM di Indonesia tidak lepas dari berbagai masalah. Tingkat intensitas dan sifat dari masalah-masalah tersebut berbeda tidak hanya menurut jenis produk atau pasar yang dilayani, tetapi juga berbeda antar wilayah atau lokasi, antar sentra, antar sektor atau subsektor atau jenis kegiatan, dan antar unit usaha dalam kegiatan atau sektor yang sama. Meski demikian masalah yang sering dihadapi oleh usaha mikro dan kecil adalah (Dewata, 2016):

1. Kesulitan pemasaran

Pemasaran sering dianggap sebagai salah satu kendala yang kritis bagi perkembangan UMKM. Salah satu aspek yang terkait dengan masalah pemasaran adalah tekanan-tekanan persaingan, baik pasar domestik dari produk serupa buatan usaha besar dan impor, maupun di pasar ekspor.

2. Keterbatasan Finansial

UMKM di Indonesia menghadapi dua masalah utama dalam aspek finansial yakni mobilitas modal awal (star-up capital) dan akses ke modal kerja. 
Financial jangka panjang untuk investasi yang sangat diperlukan demi pertumbuhan output jangka panjang.

3. Keterbatasan SDM

Keterbatasan SDM merupakan salah satu kendala serius bagi banyak UMKM di Indonesia, terutama dalam aspek-aspek manajemen, teknik produksi, pengembangan produk, engineering, quality control, organisasi bisnis, akuntansi, data processing, teknik pemasaran, dan penelitian pasar.

4. Masalah bahan baku

Keterbatasan ini dikarenakan harga baku yang terlampau tinggi sehingga tidak terjangkau oleh UMKM atau jumlahnya terbatas.

5. Keterbatasan teknologi

UMKM di Indonesia umumnya menggunakan teknologi lama atau tradisional. Keterbelakangan teknologi ini tidak hanya membuat rendahnya total factor productivity dan efisiensi di dalam proses produksi, tetapi juga rendahnya kualitas produk yang dibuat.

\section{Pemberdayaan}

Pemberdayaan memiliki makna berbeda di Indonesia. Di Barat istilah tersebut diterjemahkan sebagai empowerment. Pemberdayaan di Indonesia adalah memberi "daya" bukan "kekuasaan". Istilah yang paling tepat adalah "energize" atau memberi "energi". Pemberdayaan adalah pemberian energi agar mampu untuk bergerak secara mandiri (Suharto, 2010). Berkenaan dengan pemaknaan konsep pemberdayaan, inti dari pemberdayaan meliputi tiga hal yaitu pengembangan, (enabling), memperkuat potensi atau daya (empowering), dan terciptanya kemandirian. Pada hakikatnya pemberdayaan merupakan penciptaan iklim yang memungkinkan potensi untuk berkembang (Winarni, 1998).

Tujuan yang ingin dicapai dari pemberdayaan adalah membentuk individu dan masyarakat/kelompok menjadi mandiri. Kemandirian tersebut meliputi kemandirian berpikir, bertindak, dan mengendalikan apa yang dilakukan. Kemandirian merupakan suatu kondisi yang ditandai oleh kemampuan untuk memikirkan, memutuskan serta melakukan sesuatu yang dipandang tepat demi mencapai pemecahan masalah-masalah yang dihadapi dengan mempergunakan daya dan kemampuan yang terdiri atas kemampuan kognitif, konatif, psikomotorik, dengan pengerahan sumber daya yang dimiliki oleh lingkungan internal sehingga untuk menuju mandiri perlu dukungan kemampuan berupa sumber daya manusia yang utuh dengan kondisi kognitif, konatif, psikomotorik dan afektif, dan sumber daya lainnya yang bersifat fisikmaterial (Sulistyani, 2004). Terdapat 7 tahap pemberdayaan yaitu sebagai berikut (Jamasi, 2004):

1. Tahap Persiapan

Pada tahapan ini ada dua tahapan yang harus dikerjakan yaitu penyiapan petugas dan penyiapan lapangan.

2. Tahapan Pengkajian

Pada tahapan ini proses pengkajian dapat dilakukan secara individual melalui kelompok-kelompok dalam masyarakat. Dalam hal ini petugas harus berusaha mengidentifikasi masalah kebutuhan yang dirasakan (feel needs) dan juga sumber daya yang dimiliki klien.

3. Tahap Perencanaan Alternative Program 
Pada tahapan ini petugas sebagai agen perubahan (exchange agent) secara partisipatif mencoba melibatkan sasaran untuk berfikir memecahkan permsalahan yang dihadapi.

4. Tahap Perfomalisasi Rencana Aksi

Pada tahapan ini agen perubahan membantu sasaran untuk merumuskan dan menentukan program untuk mengatasi permasalahan yang ada. Disamping itu juga petugas membantu untuk memformulasikan gagasan kedalam bentuk tertulis, terutama bila ada kaitannya dengan pembuatan proposal kepada penyandang dana.

5. Tahap Implementasi Program

Dalam pelaksanaan program pemberdayaan, sasaran diharapkan dapat menjaga keberlangsungan program yang telah dikembangkan. Kerjasama merupakan hal penting dalam tahapan ini karena terkadang sesuatu yang sudah direncanakan dengan baik melenceng saat dilapangan.

6. Tahap Evaluasi

Evaluasi sebagai proses pengawasan dilakukan secara bersama antara petugas pelaksana dan kelompok sasaran serta dengan membentuk suatu sistem untuk pengewasan secara internal dan untuk jangka panjang.

7. Tahap terminasi

Tahap terminasi merupakan tahapan pemutusan hubungan secara formal dengan komunitas sasaran.

\section{METODE PELAKSANAAN}

Alat yang digunakan dalam kegiatan ini yakni laptop, infokus, dan alat tulis. Kegiatan ini dilaksanakan di UMKM Cendawan House Kelurahan Tebing Tinggi Okura Kecamatan Rumbai Pesisir Kota Pekanbaru pada bulan Juli 2019. Metode yang digunakan yakni sosialisasi, diskusi, dan tanya jawab. Adapun kegiatan yang dilakukan yakni:

1. Melakukan Survey ke lokasi pengabdian

2. Melakukan kegiatan perkenalan diri, prodi, dan kampus

3. Menjelaskan maksud dan tujuan kedatangan

4. Mendata anggota UMKM Cendawan House

5. Merumuskan kekuatan, kelemahan, peluang dan tantangan UMKM Cendawan House

6. Melakukan sosialisasi dan pemberdayaan UMKM

7. Melakukan diskusi dan tanya jawab

8. Evaluasi pelaksanaan kegiatan

\section{HASIL DAN PEMBAHASAN}

Hasil dari kegiatan berupa pemberdayaan Usaha Mikro Kecil Menengah Cendawan House adalah saat ini UMKM tersebut telah memiliki pembukuan yang baik sehingga pengelolaan keuangan menjadi lebih rapi, transparan, dan dapat dipertanggung jawabkan kepada seluruh anggota UMKM. Usaha Mikro Kecil Menengah Cendawan House Cendawan House juga telah memiliki struktur dan pembagian tugas yang jelas sehingga setiap anggota UMKM ini telah memiliki tugas dan tanggung jawab masingmasing, selain itu juga talah disepakati batasan-batasan yang jelas, baik itu pekerjaan maupun wewenang dalam menjalankan aktivitas usaha mengingat UMKM ini dimiliki 
secara bersama sehingga sangat memerlukan hal tersebut agar aktivitas usaha yang dilakukan berjalan optimal. Dengan demikian maka semua fungsi manajemen usaha, yakni mulai dari proses penanaman/pembenihan jamur (pembuatan baglog), perawatan dan panen, pengolahan jamur menjadi makanan siap saji bernilai ekonomis tinggi, hingga pemasaran produk berjalan dengan baik.

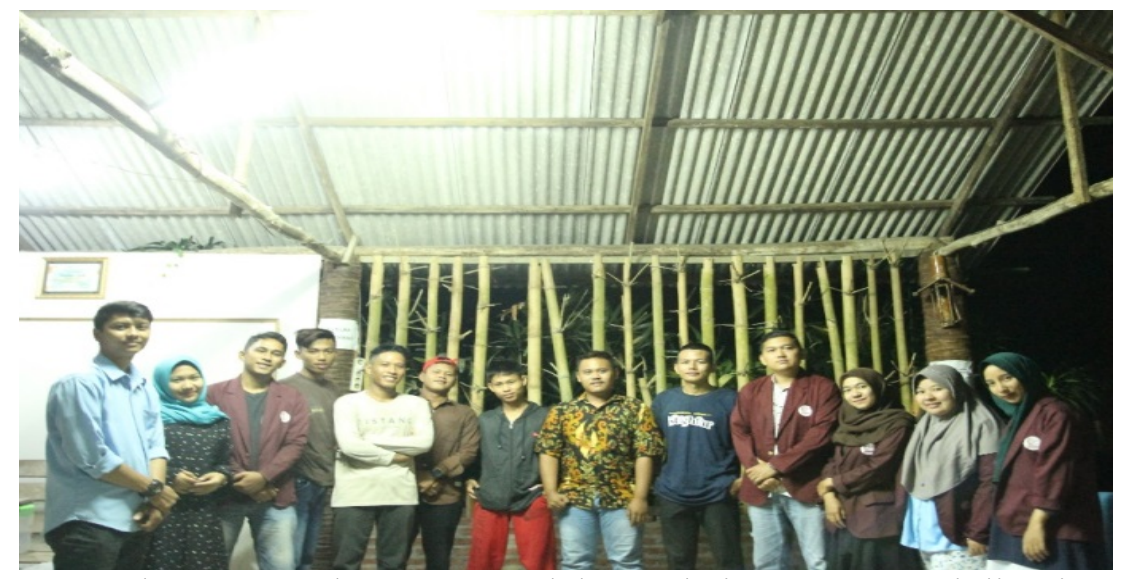

Gambar 1. Foto bersama setelah rangkaian proses sosialisasi

Usaha Mikro Kecil Menengah Cendawan House telah memasarkan jamur tiram olahan berupa pizza jamur, jamur krispi, nugget jamur, dan sate jamur sebagai hasil produksinya melalui sosial media berupa facebook dan instagram sehingga produk UMKM Cendawan House akan lebih dikenal masyarakat luas serta akan menigkatkan nilai jual produk karena penggunaan sosial media untuk pemasaran produk ini lebih difokuskan pada jamur tiram olahan sehingga memiliki nilai ekonomis tinggi dan lebih menargetkan pada konsumen generasi muda dimana mayoritas saat ini merupakan pengguna sosial media. Selain itu juga produk UMKM Cendawan House ini telah mulai dipasarkan di supermarket-supermarket yang ada di Kota Pekanbaru, bahkan telah menjalin kerjasama dengan bebarapa pengusaha kuliner, baik rumah makan maupun pengusaha olahan jamur sebagai memasok jamur tiram segar.

UMKM ini juga tentunya tetap mempertahankan dan berupaya meningkatkan penjualan di pasar tradisional dengan memasarkan produknya di bebrapa pasar tradisional yang ada di Kota Pekanbaru. Usaha Mikro Kecil Menengah Cendawan House juga telah menyediakan fasilitas antar pesanan, baik jamur tiram mentah maupun jamur tiram olahan sehingga lebih menarik perhatian dan minat konsumen mengingat lokasi UMKM ini yang berada cukup jauh dari pusat kota. Hal ini tentunya dapat berjalan dengan baik setelah adanya pembukuan, struktur, dan pembagian tugas yang jelas antar anggota sehingga aktivitas usaha yang dilakukan dapat dilakukan secara sehat. 


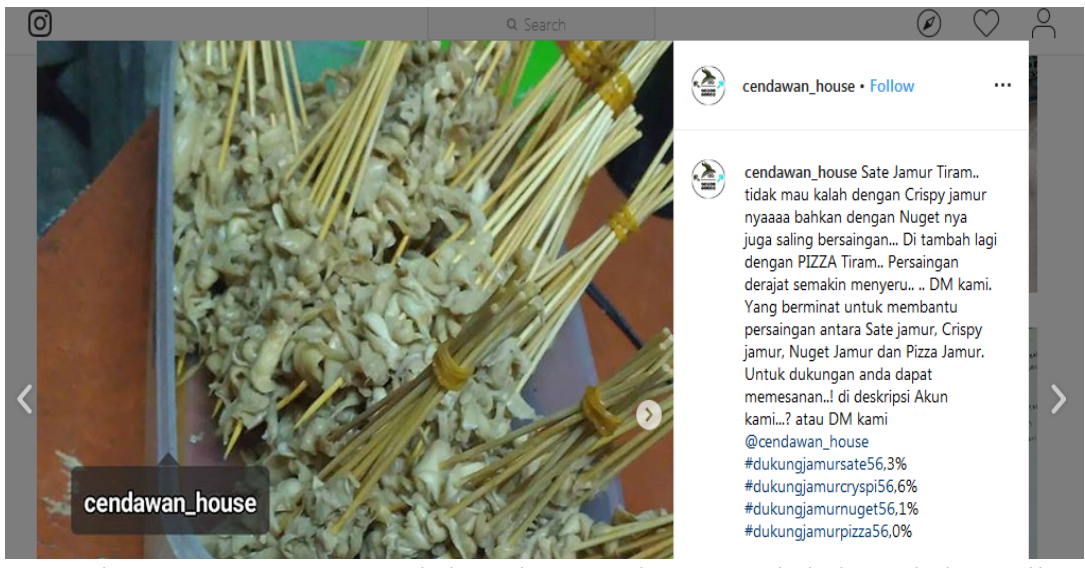

Gambar 2. Pemasaran olahan jamur tiram melalui sosial media

\section{KESIMPULAN}

Dari kegiatan yang telah dilaksanakan, dapat disimpulkan bahwa pengetahun dan pemahaman mitra meningkat, hal ini dapat dilihat dengan telah adanya pembukuan yang baik, struktur, dan pembagian tugas yang jelas dalam menjalankan aktivitas usaha. Selain itu dengan sudah dimilikinya hal tersebut juga berdampak positif terhadap produksi dan pemasaran, baik dalam bentuk jamur tiram segar maupun olahan sehingga meningkatkan profit mitra. Permasalahan yang dihadapi mitra dapat terselesaikan setelah mengikuti kegiatan pengabdian ini. Untuk lebih meningkatkan kapasitas dari UMKM ini tentunya diperlukan upaya pendampingan berkelanjutan sehingga mitra termotivasi dan terus berkembang. Penulis mengucapkan terimakasih kepada semua pihak yang telah mendukung terlaksananya kegiatan ini.

\section{DAFTAR PUSTAKA}

[1]. Abeng, T. (2015) BUMR Badan Usaha Milik Rakyat Lembaga Pelaku Ekonomi dan Keuangan Inklusif. Jakarta: Elex Media Komputindo.

[2]. Dewata, M. F. N. (2016) UMKM di Indonesia Perspektif Hukum Ekonomi. Yogyakarta: Pustaka Pelajar.

[3]. Jamasi, O. (2004) Keadilan, Pemberdayaan, dan Penanggulangan Kemiskinan. Jakarta: Belantika.

[4]. Suharto, E. (2010) Membangun Masyarakat Memberdayakan Rakyat. Bandung: Refika Aditama.

[5]. Sulistyani, A. T. (2004) Kemitraan dan Model-Model Pemberdayaan. Yogyakarta: Graha Ilmu.

[6]. Tambunan, T. (2012) Usaha Mikro Kecil dan Menengah di Indonesia : Isu-Isu Penting. Jakarta: LPE3S.

[7]. Winarni, T. (1998) Memahami Pemberdayaan Masyarakat Desa Partisipatif dalam Orientasi Pembangunan Masyarakat Desa Menyongsong Abad 21: Menuju Pemberdayaan Pelayanan Masyarakat. Yogyakarta: Aditya Media.

[8]. Yustika, A. E. (2007) Perekonomian Indonesia. Malang: BPFE- UNIBRAW. 